\title{
28 Research Suare \\ Urbanization Affects the Occurrence of a Large Stingless Bee Species in a Large City
}

Yasmine Antonini ( $\square$ antonini.y@gmail.com )

Federal University of Ouro Preto https://orcid.org/0000-0002-5582-8193

Rogerio Parentoni Martins

Universidade Federal do Ceara

Research Article

Keywords: Stingless bees, landscape, conservation, remnant fragments

Posted Date: January 31st, 2022

DOI: https://doi.org/10.21203/rs.3.rs-594102/v1

License: (9) This work is licensed under a Creative Commons Attribution 4.0 International License.

Read Full License 


\section{Abstract}

Insightful studies of habitat fragmentation and bees will consider fragmentation, alteration, and loss of nesting habitats, not just patches of forage plants, as well as the permeability of the surrounding matrix to interpatch movement. Most previous studies on bees defined habitat fragments as remnant patches of floral hosts or forests, overlooking the nesting needs of bees, with their conclusions being that habitat fragmentation is broadly deleterious, but there still remain contrasting results in the literature. We investigated the effects of fragmentation, caused by urbanization, and the permeability of the surrounding matrix on the occurrence of one species of large-sized stingless bee. Individuals of Melipona quadrifasciata were collected at flowering plants in 11 Atlantic Forest fragments (ranging 64-1,406 ha) in southeastern Brazil and analyzed the vegetation structure of the fragments and classified the urbanized matrix. We examined the effects of forest fragment size, fragment isolation and the urban landscape context on the occurrence of $M$. quadrifasciata. We found the species to be highly dependent on large and tall trees and was found in large fragments with high tree species richness and tree density. The urbanized landscape context was also found to be directly related to the presence of $M$. quadrifasciata, with the species' absence from fragments in a highly urbanized landscape. We conclude that habitat quality within a fragment (vegetation structure), as well as matrix quality, are directly related to the occurrence of $M$. quadrifasciata, as shown by the direct relationship between environmental structural diversity and fragment age. The matrix holding recent fragments, probably due to the sprawl of the city, is more heterogeneous than the one with the oldest fragments. The most heterogeneous matrices possess a certain balance between trees, buildings and bare soil or herbaceous vegetation coverage, making them less impermeable to bees.

\section{Introduction}

Human fragmented landscapes maintain some degree of connectivity via the matrix of modified habitat surrounding them. It has become increasingly apparent that to understand how fragmentation affects bee species it is necessary to obtain information on their reaction to all landscape components, i.e., forest patches, intervening matrix and urbanization gradient (Banaszak-Cibicka and Zmihorski 2012; Fortel et al 2014). From the perspective of an invertebrate pollinator, habitat fragmentation may not only include the existence of isolated or patchy habitats, but also the lack of intervening habitat (Aizen and Feinsinger 2003, Bennett and Saunders 2010).

Ecological research in recent years has devoted increasing attention to urbanization (Hahs and Evans 2015), reflecting the growing impact of land use on biodiversity (Grimm et al. 2008). Over half of the world's human population currently resides in cities, which is predicted to reach $68 \%$ by 2050 (United Nations 2018). Much of the knowledge about the impacts of land use change and the consequences of the fragmentation for bee communities has come from studies in natural areas and agricultural environments (see a revision in Winfree et al., 2009), whereas the impacts of urbanization are less well understood. 
Because the extent of urbanized areas is increasing rapidly (Seto et al., 2013, Threlfall et al 2015), management of urban bee assemblages will become increasingly important as they play a vital role in the persistence of the wild and managed plants therein (Cane et al., 2006; Williams and Winfree, 2013). For example, Pauw and Hawkins (2011) highlighted the parallel declines of insect pollinators and associated insect pollinated plants in urban conservation reserves in South Africa.

Several potential drivers and emerging threats to wild and managed bees have been identified. Habitat loss (including intensified urbanization) leading to loss of forage and nesting resources has been a major driver of bee declines in the 20th century (Le Féon et al. 2010; Potts et al. 2010a; Marshall et al. 2017; Papanikolaou et al. 2017a). A review of 59 studies by Hernandez et al. (2009) found that bee species richness was generally negatively correlated with urbanization and/or anthropogenic modifications, while a meta-analysis by Winfree et al. (2009) found a similar negative effect of habitat loss or fragmentation on bee abundance and species richness, although the magnitude of the effect was small. However, results from individual studies show a varied and often contradictory picture. For example, negative correlations with urbanization were found for: wild bee species richness in Pennsylvania, USA (Choate et al. 2018); bee diversity and abundance in Birmingham, UK (Bates et al. 2011); and stingless bees and eusocial wasps richness in Belo Horizonte, Brazil (Zanette et al. 2005). A temporal comparison of bee communities pre- and post-urbanization in Brazil also indicated negative impacts of land-use change (Cardoso and Gonçalves 2018).

However, the impacts of urbanization on stingless bees, the most diverse group (over 500 species worldwide) of all eusocial bees, are underestimated (see Winfree et al 2009, Antonini et al 2012). These bees have a particular distinctiveness that must be considered to better understand how they could be impacted by human disturbance and fragmentation. For example, some species live in permanent colonies in cavities of live trees and possess low-range flight (Michener 2007).

Removal of vegetation negatively impacts stingless bee assemblages (Allen-Wardell et al. 1998; Kremen et al. 2007), as does the loss structure of forest remnants left in the landscape (Loyola and Martins 2008; $2009 ; 2011$, Antonini et al 2012). Vegetation quality in the surrounding matrix is also relevant (Antonini et al 2012), because matrix vegetation will act as a selective environmental filter of the movements of individuals (e.g., a highly urbanized matrix lacking vegetation is a "small pore" filter). Thus, colonies are unable to escape from urbanized areas if there is no vegetation. Moreover, during the natural division of a colony, workers provision a new nest site before the colony divides to occupy it (Roubik 1989), which does not allow colonies to disperse for more than a few hundred meters (Michener 2007).

The genus Melipona comprises more than 50 species restricted to Central and South America (Camargo \& Menezes-Pedro, 1992). The species of the genus have varied nesting habits: they build underground nests in hollow roots, in hollows in tree trunks or in abandoned nests of other insects such as termites and ants. The nest is constituted, internally, basically of cerumen (a mixture of wax and propolis) that is isolated with clay (Nogueira-Neto 1997). Melipona quadrifasciata uses tree hollows to nest with an entrance orifice of one to three meters in height (Antonini and Martins 2003), although nests have been 
found with entrances of up to seven meters in height (Antonini and Martins 2003). Melipona quadrifasciata was selected for this study because, although general aspects of its biology have been previously described, there have been no studies indicating which habitat characteristics of an urbanized landscape are determinant for its occurrence.

Here, we examined the effects of forest fragment size and fragment isolation, in the context of an urban landscape, on the occurrence of Melipona quadrifasciata. We hypothesized that M. quadrifasciata would respond to landscape factors (degree of urbanization and human disturbance), according to its life history, and that fragment size will determine occurrence, with less probability for smaller than larger fragments. Furthermore, vegetation structure (species richness, abundance and density of trees; trunk diameter and canopy height) will also determine the occurrence of M. quadrifasciata in fragments due to the specific habitat requirements of the species.

\section{Methods}

\section{Study sites}

Our study focused on sites located in the countryside surrounding the city of Belo Horizonte, Minas Gerais, Brazil (Fig. 1). The landscape in this area is largely (> 85\%) deforested, with the main land uses being urbanization, pasture and rural subsistence crops. All the study sites have suffered from various forms of human disturbance, such as fire, non-programmed urbanization and selective logging. Most of the current modifications took place with the settlement of Belo Horizonte toward the end of the $1800 \mathrm{~s}$, however, all the study sites have been converted to natural protected areas in the last century. We choose 11 forest fragments (study sites) varying in size from 1.2ha to 1,406ha. The sites consist of semi-mature forest disturbed by humans (experiencing selective logging in the past and are at least $1.5 \mathrm{~km}$ (maximum distance $3.0 \mathrm{~km}$ ) distant from each other. See Table 1 for names and characteristics of each forest fragment. 
Table 1

Sites names and, size, and presence of M. quadrifasciata

\begin{tabular}{|c|c|c|c|c|}
\hline $\begin{array}{l}\text { Site } \\
\text { sigla }\end{array}$ & Site name & $\begin{array}{l}\text { Size } \\
\text { (ha) }\end{array}$ & $\begin{array}{l}\text { Average distance to the } \\
\text { neighbor fragment }\end{array}$ & $\begin{array}{l}\text { Occurrence of } M \text {. } \\
\text { quadrifasciata }\end{array}$ \\
\hline $\begin{array}{l}1- \\
\text { APEB }\end{array}$ & APE Barreiro & 1,406 & $1.3+0.3$ & Yes \\
\hline 2-PBT & Parque Betania & 25 & $1.7 \pm 1.3$ & No \\
\hline 3-APS & $\begin{array}{l}\text { Parque Ageo Pinho } \\
\text { Sobrinho }\end{array}$ & 27 & $1.5 \pm 1.4$ & No \\
\hline $\begin{array}{l}4- \\
\text { PCAI }\end{array}$ & Parque Caiçara & 1.2 & $2.0 \pm 1.0$ & No \\
\hline 5 -EE & $\begin{array}{l}\text { Estação Ecológica da } \\
\text { UFMG }\end{array}$ & 64 & $1.5+0.3$ & Yes \\
\hline $\begin{array}{l}\text { 6- } \\
\mathrm{MJB}\end{array}$ & Mata do Jambreiro & 912 & $1.1 \pm 0.2$ & Yes \\
\hline $\begin{array}{l}\text { 7- } \\
\text { PFLN }\end{array}$ & $\begin{array}{l}\text { Parque Fazenda Lagoa } \\
\text { do Nado }\end{array}$ & 30 & $3.0 \pm 1.5$ & No \\
\hline $\begin{array}{l}\text { 8- } \\
\text { PMGB }\end{array}$ & $\begin{array}{l}\text { Parque das } \\
\text { Mangabeiras }\end{array}$ & 235 & $2.0 \pm 0.8$ & Yes \\
\hline $\begin{array}{l}9- \\
\text { MHN }\end{array}$ & $\begin{array}{l}\text { Museu de História } \\
\text { Natural da UFMG }\end{array}$ & 64 & $2.0 \pm 0.3$ & Yes \\
\hline $\begin{array}{l}10- \\
\text { PUAM }\end{array}$ & $\begin{array}{l}\text { Parque Ursulina } \\
\text { Andrade de Melo }\end{array}$ & 24 & $2.4 \pm 2.0$ & No \\
\hline $\begin{array}{l}11- \\
\text { FZB }\end{array}$ & Fundação Zoobotânica & 145 & $3.0 \pm 1.0$ & Yes \\
\hline
\end{tabular}

\section{Bee Sampling}

To discover the occurrence of $M$. quadrifasciata in each site, we sampled foraging bees once a week, using entomological nets, from April 1998 to December 2000. We searched for bees in all flowering herbaceous-shrub plants and trees with canopies below five meters.

\section{Fragment Attributes}

We sampled vegetation attributes in each site using the method of vegetation quadrats (Cottam \& Curtis, 1956). We performed phytosociological analyses using the program FITOPAC (Shepherd 2012) with the following variables: plant species richness, plant abundance, tree density, tree DBH (diameter at breast high) and tree height. We determined the floristic composition of each fragment after plant identification by specialists of the herbarium of UFMG (BHCB). The amount of time in isolation of each site was 
obtained at the public archives from the City Hall of Belo Horizonte. The number of vegetation strata in each site was established from a frequency histogram of height classes with an interval of $0.5 \mathrm{~m}$.

\section{Matrix Attributes}

We assessed the impact of forest remnant size, isolation and landscape context of each site on the presence of $M$. quadrifasciata. To assess these factors, we used a combination of geographic information system (GIS) and ground-based surveys, as well as a digital repository of aerial photographs of each site. We used the images to describe the structure of the matrix surrounding each of the studied sites (following Schultz and Crone 2001 and Antonini et al 2013) and analyzed 15 images for studied site plus surrounding matrix corresponding to $480,000 \mathrm{~m}^{2}$. We constructed an equal-area grid of 783 grid cells, with each cell being equal to $613 \mathrm{~m}^{2}$ of the area, to completely encompass the image. We then numbered each cell: 1 - forest cover; 2 - non-forested green area, composed mainly of herbaceous vegetation or cleared land; and 3 - area impervious to water, composed of buildings and roads. We used the total number of cells to obtain the percentages of forest cover, non-forested green area, and impervious area. After categorizing $(1,2,3)$ the cells, we determined their distribution among categories to the percentages for each one. We then used the Shannon-Wiener diversity index to compute the structural diversity of the matrix surrounding each site (Supplementary Fig. 1). The values were then subjected to Spearman correlation analysis to discover any relationships between site age and structural diversity of the matrix surrounding each fragment/site.

\section{Degree Of Human Intervention}

As used here, "degree of human intervention" refers to artificially caused alterations that compromise the quality of natural habitats (with negative effects on species, populations and communities of animals and plants). These changes include the insertion of trails, roads and buildings within the fragments. It is assumed that the greater the human alteration, the worse or potentially worse a particular surface becomes with regard to the primitive natural resources it houses. The same methodology used to analyze the matrix surrounding each fragment was used to categorize the degree of intervention. The results made it possible to separate fragments into categories, with each receiving a value ranging from 0 to 2 . Thus, 0 was assigned to fragments with virtually no intervention, 1 to those with extensive intervention and 2 to those with very extensive intervention.

\section{Data analysis}

We tested the effects of site size and isolation, as well as of the matrix context, on the presence of $M$. quadrifasciata. We also tested bee presence against landscape metrics (such as degree of urbanization), among-site attributes (isolation and size) and within-site attributes (phytosociological variables such as tree species abundance and diversity). 
We calculated site isolation by measuring the distance from each site to the four nearest neighbouring remnants using the point-quadrat method (Cottam and Curtis 1956; Krebs 1999) and a classified Landsat image of Belo Horizonte (1:25.000). Thus, we used the average of the distances between a specific fragment and its four nearest neighbours as a measure of isolation. An ANOVA was used to evaluate differences among sites in the size of 20 individual bees (measured through tegula distance raised to the cube).

In order to assess the effects of site isolation on worker size, a regression was performed between average worker size and distance from the nearest fragment.

The significance of values obtained for degree of disturbance and the surrounding urbanization matrix of sites was tested by the chi-square test. Generalized linear models, with quasi- Poisson error distributions, were used to search for correlations among landscape and vegetation variables.

Bee presence was ordinated using PCA to identify patterns of bee distribution relative to: 1) tree abundance and tree diversity; 2) degree of fragment isolation; 3 ) fragment size 4) degree of urbanization and 5) degree of disturbance. Logistic regression was used to test the probability of occurrence of $M$. quadrifasciata based on the landscape and vegetation variables. All analyses were conducted with the program R (Development Core Team 2021).

\section{Results}

Melipona quadrifasciata was found in six of the 11 study sites (See Table 1).

The first two axis of the PCA explained $72.0 \%$ of the variance in the presence of $M$. quadrifasciata among sites. Fragment size, tree species richness and tree abundance and average tree height, degree of urbanization, the first principal component, and the tree abundance for the second principal component, affected bee species abundance (Fig. 2) and grouped sites where M. quadrifasciata was found.

\section{Landscape attributes and M. quadrifasciata occurrence}

We found a significant relationship between the variables disturbance intensity and degree of urbanization and the presence of $M$. quadrifasciata with first principal component extracted from the PCA, indicating that these variables were good predictors of the occurrence of $M$. quadrifasciata in the fragments/sites.

We found a significant difference between urbanization categories (high and low) and the presence of $M$. quadrifasciata $\left(\mathrm{X}^{2}=6.4, \mathrm{gl}=1, \mathrm{p}=0.011\right)$ and between disturbance categories (high and low) and the presence of $M$. quadrifasciata $\left(\chi^{2}=6.62, g l=1, p=0.36\right)$.

Simple logistic regression analysis revealed a significant relationship between the presence of $M$. quadrifasciata and the variables degree of disturbance and degree of urbanization. The variables fragment size and population density in the surrounding matrix were found not influence the presence of 
M. quadrifasciata (Fig. 3a and b). The greater the degree of disturbance and degree of urbanization of the surrounding urban matrix, the lower the likelihood of the occurrence of M. quadrifasciata. Fragments with a high degree of human disturbance had a near zero probability for the occurrence of M. quadrifasciata, while fragments with little or no disturbance had probabilities of occurrence reaching $100 \%$ (Fig. 3a and b). Melipona quadrifasciata was not recorded in fragments inserted in a matrix with greater than $90 \%$ urbanization is (Fig. 3a), while there was a $100 \%$ probability of finding M. quadrifasciata in fragments inserted in a matrix with $30 \%$ urbanization (Fig. 3a).

Worker bees from APEB were larger than those of EE $(F=5.0636, P<0.01)$ and $M J B(F=3.6951 p<0.05)$; however, worker size and degree of fragment isolation were not significantly related $\left(r^{2}=0.426, p=0.39\right)$.

\section{Vegetation structure and M. quadrifasciata presence}

Simple logistic regression analysis found a significant relationship between the presence of $M$. quadrifasciata and the variables tree species richness, tree abundance, tree density and height of trees (Table 2). The probability of occurrence of $M$. quadrifasciata was determined by tree abundance (with DBH above $40 \mathrm{~cm}$ ). The probability for the occurrence of $M$. quadrifasciata in fragments with 280 individual trees was 50\%, and can reach $100 \%$ in fragments with more than 324 individual trees (Fig. 4a).

Table 2

Regression coefficients of the logistic regression with the variables that determine the occurrence of Melipona quadrifasciata in the studied sites, Belo Horizonte, Brazil.

\begin{tabular}{|llll|}
\hline Variables & \multicolumn{2}{l}{ Regression coefficients } \\
\hline & $2 \log ($ Likelihood) & $\chi$ & $\mathrm{p}$ \\
\hline Fragment Size & - & - & $\mathrm{NS}$ \\
\hline Tree Richness & 0.007 & 15.15 & $\mathbf{0 . 0 0 0}$ \\
\hline Tree Abundance & 0.230 & 14.92 & $\mathbf{0 . 0 0 1}$ \\
\hline DBH & - & - & $\mathrm{NS}$ \\
\hline Tree Diversity & - & - & $\mathrm{NS}$ \\
\hline Tree High & 8.550 & 6.60 & $\mathbf{0 . 0 0 7}$ \\
\hline Tree density & 8.010 & 7.14 & $\mathbf{0 . 0 0 7}$ \\
\hline Disturbance & 3.810 & 11.33 & $-\mathbf{0 . 0 0 0}$ \\
\hline Urbanization & 7.190 & 07.96 & $-0,010$ \\
\hline Human density & - & - & NS \\
\hline
\end{tabular}

The probability of the occurrence of $M$. quadrifasciata was also determined by tree species richness, with it being $50 \%$ for fragments with 57 tree species (with DBH above $40 \mathrm{~cm}$ ) (Fig. 4b), and reaching 100\% in 
fragments with more than 68 species.

Melipona quadrifasciata was detected in fragments with high tree density. The probability of the species occurring in fragments with a density of 32 trees per hectare was 50\% (Fig. 4c) and reached $100 \%$ for fragments with a density greater than 89 trees per hectare (Fig. 4c).

The occurrence of M. quadrifasciata was also determined by the height of trees. The species occurred in fragments with trees of $7 \mathrm{~m}$ in height (Fig. 4d). The variables average tree DBH and tree diversity did not influence the occurrence of $M$. quadrifasciata in the studied fragments.

\section{Discussion}

In spite of more than 100 years of isolation and deforestation pressure, the results obtained here for the study sites suggest that not all, in fact just a few, of the remnant forest fragments support populations of Melipona quadrifasciata. Fragment proximity to a large, continuous forest, amount of time of fragment isolation, and fragment size all affect the persistence of $M$. quadrifasciata in urban remnant fragments.

Urban densification increasingly replaces beneficial habitats for bees with impervious surfaces and abiotic elements with little to no flowering or nesting resources. This loss of habitable area is probably enhanced because increasing urbanization also reduces the habitat quality of remaining vegetation (Hahs and McDonnell 2006). Remaining habitat patches are also increasingly isolated and fragmented within a dense urban matrix, further disfavoring bee diversity (Wenzell et al 2020, Fortel et al., 2014).

At the landscape scale, the occurrence of Melipona quadrifasciata was mostly influenced by the intensity of urbanization. Urbanization intensity can be seen as a proxy for the abiotic human-made elements in a landscape and is most often quantified as the proportion of impervious surface (Geslin et al., 2016). We found that $M$. quadrifasciata was almost absent from residential landscapes, and significantly more likely to occur in public parks and green spaces with greater proportions of native vegetation, including planted native vegetation.

The occurrence of Melipona quadrifasciata in some sites and not in others is directly related to the state of naturalness of the non-urban habitat and the progression of urban densification. Urban densification describes an increase of intermediate urbanization levels within a limited area, in contrast to urban sprawl (Vergnes et al., 2014, Wenzel et al 2020). According to Wenzel et al (2020) positive biodiversity outcomes were repeatedly connected to moderate or intermediate levels of urbanization, associated to urban sprawl. In the studied sites, the densification of the urban matrix poses a significant barrier for larger species that nest in large cavities, like M. quadrifasciata. The presence of older and tall trees are imperative to the occurrence of this bee species because they are the source and substrate of cavities with the capacity to house the species' colonies in a matrix (Antonini et al 2012, Antonini and Martins 2003). The nesting success of species that nest in wood and pith cavities has been reported to decline in urban areas where vegetation is highly maintained and woody debris is often frequently removed (Matteson et al., 2008, Threlfall et al 2015). Although, some studies have reported a greater abundance of 
cavity nesting species in more urban habitats (Fortel et al., 2014), this is likely dependent upon the substrate in which each cavity is located and the ability of species to utilize human-made materials.

The occurrence of $M$. quadrifasciata was also determined by the degree of isolation of fragments. Thus, non-urbanized areas in Belo Horizonte would serve as an ecological filter of M. quadrifasciata. According to the landscape analyses presented here, the movement of this bee species would be easier between PMGP and MJB, and more difficult between EE and its neighboring fragments. As used here, the landscape matrix refers to those urban areas that surround the studied fragments. An urban matrix in Belo Horizonte holds fragments that are permeable to some bee species, such as M. quadrifasciata, that fly short distances and is more demanding in relation to habitat. The manner by which social stingless bees find new colonies (the new colony started when the queen returns from her nuptial flight; Roubik 1989) endows these species with a limited ability to occupy new habitats. Larger bees, such as $M$. quadrifasciata, nest exclusively in pre-existing cavities in tree holes. Thus, in this case, permeability means the presence of trees with large enough hollows to house a colony. In other words, there are trees that could harbor a colony in the matrix that can serve as "stepping-stones" (MacArthur and Wilson 1967) during dispersal, from which bees could swarm to fragments and thus increase their rage. Previous work dealing with the effects of remnant isolation on the composition of stingless bee assemblages in the study area (Antonini et al 2012) demonstrated a strong shift in stingless bee composition but no differences in bee diversity. Meliponine bees that nest primarily in tree cavities markedly decline with increasing distance from forest edges, while those that use other habitats, such as soil, remain (Antonini et al 2012).

Melipona quadrifasciata only occurs in larger fragments that have certain structural features, such as the presence of tall trees with large diameters. Brown and Albrecht (2001) found that, along a gradient of deforestation, sites with preserved vegetation provide floral resources and nesting sites within bee flight range (Roubik 1989) and have higher richness of species of the genus Melipona. Melipona quadrifasciata is a generalist bee species, although previous studies have shown it to have a preference for flowers of species of the families Melastomataceae and Solanaceae for pollen harvest, and Asteraceae and Myrtaceae for nectar harvest (Guibu et al., 1988, Ramalho et al., 1990, Wilms et al., 1996, Viana et al., 1997, Antonini et al 2006). Threlfall et al. (2015) reported that the probability of occurrence of native bee species increases with increasing density of native vegetation and flower diversity. These authors found that ground-nesting native bee taxa, such as Homalictus spp., have a significantly higher probability of occurrence in older green space habitats with less surrounding impervious surface cover. Nesting substrate may be a limiting resource for cavity-nesting bees in fragments where older trees are relatively rare. Fencing, homes, and shade trees in urban areas may, in contrast, provide many suitable nesting sites. Other studies have reported a similar response of cavity-nesting bees in disturbed habitats. Cavity nesters richness were found to increase more than ground nesters in remnant meadows surrounded by German farmland (Tscharntke et al. 2005). Nesting habits for bees may be extremely useful in predicting how native bee faunas respond to habitat fragmentation in urban and, possibly, other settings. In the present study, PCAl had the highest average tree height, but M. quadrifasciata was absent, 
likely because this fragment lacked high values for the other phytosociological variables that are notably important in determining the occurrence of the species.

Vegetation quality in fragments is also important for the occurrence of M. quadrifasciata. Of the 11 fragments studied, $M$. quadrifasciata was found in six. The probability for the occurrence of $M$. quadrifasciata was higher in fragments with greater tree species richness, abundance and density and greater canopy height. According to historical records (FJP 1996), deforestation throughout the study area did not occur at the same time. Because the fragments became isolated at different times, the effects on stingless bee species have also been different. As an example, fragment NHM became separated from a large, continuous forest 60 years ago (PLAMBEL 1996) and despite its location in a highly urbanized area, we still found it to be occupied by M. quadrifasciata. There exists, outside the limits of NHM, small gardens with many tree species able to supply cavities for bees nesting. According to Rebele (1994), for some groups, plant species richness is not the most decisive factor to explain the presence or absence of certain bee species in a site, but rather structural diversity of vegetation and heterogeneity or space are important (see also Loyola \& Martins 2008, 2009). Habitat heterogeneity may be a factor that allows the permanence of some species of bees. For example, fragments SPA and MGP of the present study are particularly heterogeneous, being interspersed with elements of Cerrado (Brazilian savanna), semideciduous forest and ironstone fields. On the other hand, fragments ES and $\mathrm{NHM}$ are less heterogeneous; patches of Cerrado and semi-deciduous forest cover ES, while semideciduous forest vegetation dominates NHM. Vegetation heterogeneity may be beneficial for generalist bee species, such as M. quadrifasciata. Older fragments hold older and taller trees (Antonini \& Martins 2003) that provide more nesting sites (hollows) for M. quadrifasciata. In addition, older trees are usually in the reproductive phase and, thus, provide pollen and nectar for $M$. quadrifasciata.

A homogeneous matrix for older fragments and a heterogeneous matrix for recent fragments represents the relationship between the structural diversity of the surroundings and that of a fragment. More heterogeneous matrices possess a balance among tree coverage, buildings and bare soil or herbaceous vegetation that makes them less impermeable to bees.

Changes that occur during ecological succession are responsible for the different heights of trees in the studied fragments. Fragments in intermediate successional stages have shorter trees, while those in more mature stages have long-lived and taller trees (King \& Chapman, 1983). We observed the same situation mainly in the fragment SPA, which has been preserved for 150 years.

In conclusion, habitat quality within a fragment (vegetation structure), as well as

matrix quality, are directly related to the occurrence of $M$. quadrifasciata. This can be seen in the direct relationship between structural diversity in the environment and the amount of time of fragment isolation. The most heterogeneous matrices possess a certain balance among trees, buildings and bare soil or herbaceous vegetation coverage, making them less impermeable to $M$. quadrifasciata. A matrix that holds young fragments, probably due to urban sprawl, is more heterogeneous than one with old 
fragments. Finally, it is very important to keep these sites protected for the conservation of this rare bee species in urban areas.

\section{Declarations}

\section{Funding}

The PROBIO (Brazilian Program for Biodiversity Conservation) program provided grants for this study

Conflicts of interest/Competing interests

The authors declare that there is no conflict of interest

Availability of data and material (data transparency)

Under request

Code availability (software application or custom code)

Not applicable

Authors' contributions:

YA and RPM participate in the conception of the work;YA in the acquisition, analysis, and interpretation of data for the work;

YA and RPM draft the work and revise it

YA and RPM approved the final version to be published

Additional declarations for articles in life science journals that report the results of studies involving humans and/or animals

Not applicable

Ethics approval (include appropriate approvals or waivers)

Not applicable

Consent to participate (include appropriate statements)

Yasmine Antonini and Rogerio Parentoni Martins declare that both are in accordance with the content of the manuscript.

\section{References}


Allen-Wardell, G. et al. (1998). The potential consequences of pollinator declines on the conservation of biodiversity and stability of food crop yields. Conservation Biology 12:8-17.

Aizen MA, Feinsinger P. 2003. Bees not to be? Responses of insect pollinator faunas and flower pollination to habitat fragmentation. pp. 111-129. In Bradshaw GA, Marquet PA, eds. How landscapes change. Springer-Verlag, Berlin, Germany. 384 pp.

Antonini, Y. Soares, SM, Martins, RP. 2003. Pollen and néctar harvesting by the stingless bee Melipona quadrifasciata anthidioides (Apidae: Meliponini) in an urban forest fragment in Southeastern Brazil. Studies on Neotropical Fauna and Environment. 41:209-215.

Antonini Y, Martins RP 2003. The value of a tree species (Caryocar brasiliense) for a stingless bee Melipona quadrifasciata quadrifasciata Journal of Insect Conservation 7: 167-174, 2003.

Antonini, Y., Martins, R.P., Aguiar, L.M., Loyola, R.D., 2013. Richness, composition and trophic niche of stingless bee assemblages in urban forest remnants. Urban Ecosyst. 16, 527-541.

https://doi.org/10.1007/s11252-012-0281-0.

Banaszak-Cibicka, W., Z_mihorski, M., 2012. Wild bees along an urban gradient: winners and losers. J. Insect Conserv. 16, 331-343.

Bennett AF, Saunders DA. 2010. Habitat fragmentation and landscape change. pp. 88-106. In Sodhi NS, Ehrlich PR, eds. Conservation Biology for All. Oxford University Press, Oxford, 360 pp.

Brown CJ, Albrecht C (2001) The effect of deforestation on stingless bees of the genus Melipona (Insecta: Hymenoptera: Apidae: Meliponini) in central Rondonia, Brazil. Journal of Biogeography 28:623634.

Camargo J.M.F. and Menezes-Pedro S.R. (1993). Systematics, phylogeny and biogeography of the Meliponinae (Hymenoptera, Apidae): a mini-review.

Cane, J.H., Minckley, R.L., Kervin, L.J., Roulston, T.H., Williams, N.M., 2006. Complex responses within a desert bee guild (Hymenoptera: Apiformes) to urban habitat fragmentation. Ecol. Appl. 16, 632-644.

Cardoso, M.C., Gonçalves, R.B., 2018. Reduction by half: the impact on bees of 34 years of urbanization. Urban Ecosyst. 21, 1-7. https://doi.org/10.1007/s11252-018-0773-7.

Cottam G, Curtis JT (1956) The use of distance measures in phytosociological sampling. Ecology 37: 451-460.

Fortel, L., Henry, M., Guilbaud, L., Guirao, A.L., Kuhlmann, M., Mouret, H., Rollin, O., Vaissière, B.E., 2014. Decreasing abundance, increasing diversity and changing structure of the wild bee community (Hymenoptera: Anthophila) along an urbanization gradient. PLoS ONE 9, e104679. 
Geslin, Bb., Le Feon, V., Folschweiller, M., Flacher, F., Carmignac, D., Motard, E., Perret, S., Dajoz, I., 2016. The proportion of impervious surfaces at the landscape scale structures wild bee assemblages in a densely populated region. Ecol. Evol. 6, 6599-6615. https://doi.org/10.1002/ece3.2374.

Grimm NB, Faeth SH, Golubiewski NE, Redman CL, Wu J, Bai X, Briggs JM (2008) Global Change and the Ecology of Cities. Science 319:756-760

Guibu, L.S.; Ramalho, M.; Kleinert-Giovannini, A. \& Imperatriz-Fonseca, V.L. 1988. Exploração de Recursos Florais por Colônias de Melipona quadrifasciata (Apidae: Meliponinae). Revista Brasileira de Biologia. 48(2):299-305.

Hahs AK, Evans KL (2015) Expanding fundamental ecological knowledge by studying urban ecosystems. Functional Ecology 29:863-867

Hahs AK, Mcdonnell MJ (2006) Selecting independent measures to quantify Melbourne's urban-rural gradient. Landscape and Urban Planning 78:435-448

Hernandez, J.L., Frankie, G.W., Thorp, R.W., 2009. Ecology of urban bees: a review of current knowledge and directions for future study. Cities Environ. 2, 3.

Kerr WE, Carvalho GA, Nascimento VA (1999) The probable consequences of the destruction of Brazilian stingless bees. Pp. 395-403, In : Padoch, C.; Ayres, J.M.; Pinedo_Vasquez, M. \& Henderson, A. (eds). Várzea: diversity, development, and conservation of Amazonia's whitewater floodplains. The New York Botanical Garden Press, New York.

King, G.C.\& Chapman, W.S. 1983. Floristic composition and structure of a rainforest area 25 years after logging. Australian Journal of Ecology 5:173-185.

Krebs, C.J. 1999. Ecological Methodology. Benjamim/Cummings Menlo Park, CA.

Kremen et al. (2007) Pollination and other ecosystem services produced by mobile organisms: a conceptual framework for the effects of land-use change. Ecology Letters, 10, 299-314.

Le Féon V, Schermann-Legionnet A, Delettre Y, Aviron S, Billeter R, Bugter R, Hendrickx F, Burel F (2010) Intensification of agriculture, landscape composition and wild bee communities: A large scale study in four European countries. Agriculture, Ecosystems \& Environment 137:143- 150

Loyola, RD \& Martins, RP. 2008. Habitat structure components are effective predictors of trap-nesting Hymenoptera diversity. Basic and Applied Ecology, 9(6): 735-742.

Loyola, RD \& Martins, RP. 2009. On a habitat structure-based approach to evaluating species occurrence: cavity-nesting Hymenoptera in a secondary tropical forest remnant. Journal of Insect Conservation, 13: 125-129. 
Loyola RD \& Martins RP (2011). Small-scale area effect on species richness and nesting occupancy of cavity-nesting bees and wasps. Revista Brasileira de Entomologia. 55(1): 69-74

Michael L. McKinney Effects of urbanization on species richness: A review of plants and animals Urban Ecosyst (2008) 11:161-176

Mac Arthur, R.H. and Wilson, E.O. 1967. The theory of island biogeography. Princeton University Press, New Jersey.

Marshall L, Biesmeijer JC, Rasmont P, Vereecken NJ, Dvorak L, Fitzpatrick U, Neumayer J, Ødegaard F, Paukkunen JPT, Vray S, Dendoncker N (2017) The interplay of climate and land use change affects the distribution of EU bumblebees d e. Global Change Biology 00:1-16

Marzluff JM, Ewing K (2001) Restoration of fragmented landscapes for the conservation of birds: a general framework and specific recommendations for urbanizing landscapes. Restor Ecol 9:280-292

Michener CD. 2007. The Bees of the World. 2nd ed. The John Hopkins University Press; Baltimore, USA. $953 \mathrm{pp}$.

Nogueira-Neto, P. 1997. Vida e criação de abelhas indígenas sem ferrão. São Paulo: Noguirapis, 1997.

Pauw, A., Hawkins, J.A., 2011. Reconstruction of historical pollination rates reveals linked declines of pollinators and plants. Oikos 120, 344-349.

Papanikolaou AD, Kühn I, Frenzel M, Kuhlmann M, Poschlod P, Potts SG, Roberts SPM, Schweiger O (2017a) Wild bee and floral diversity co-vary in response to the direct and indirect impacts of land use. Ecosphere 8:e02008

PLAMBEL 1996. Plano Metropolitano de Belo Horizonte. Prefeitura de Belo Horizonte, MG. https://prefeitura.pbh.gov.br/sites/default/files/estrutura-de governo/politica urbana/Lei_7165_Plano_Diretor. Acesso em 23/12/1999.

Potts, S.G., Biesmeijer, J.C., Kremen, C., Neumann, P., Schweiger, O., Kunin, W.E., 2010. Global pollinator declines: trends, impacts and drivers. Trends Ecol. Evol. 25, 345-353.

R Development Core Team (2021) R: A Language and Environment for Statistical Computing. R Foundation for Statistical Computing, Vienna

Ramalho,M.; Kleinert-Giovannini, A. \& Imperatriz-Fonseca, V.L 1990. Important bee plants for stingless bees (Melipona and Trigonini) and Africanized honey bees (Apis mellifera) in neotropical habitats: a review. Apidologie 21:469-488.

Rebele, F.1994. Urban ecology and special features of urban ecosystems. Global Ecology and Biogeography Letters 4:173-187 
Roubik, D.W. 1989. Ecology and Natural History of Tropical Bees. Cambridge University Press. 514pp.

Seto, K.C., Parnell, S., Elmqvist, T., 2013. A global outlook on urbanization. In: Elmqvist, T., Fragkias, M., Goodness, J., Güneralp, B., Marcotullio, P.J., McDonald, R.I., Parnell, S., Schewenius, M., Sendstad, M., Seto, K.C., Wilkinson, C. (Eds.), Urbanization, Biodiversity and Ecosystem Services: Challenges and Opportunities: A Global Assessment. Springer, Netherlands, pp. 1-12.

Shepherd, G.J. FITOPAC. Versão 2.1. Campinas, SP: Departamento de Botânica, Universidade Estadual de Campinas - UNICAMP. 2012.

Schultz CB, Crone EE (2001) Edge-mediated dispersal behavior in a prairie butterfly. Ecology 82:18791892

Steffan-Dewenter I (2002) Landscape context affects trap-nesting bees, wasps, and their natural enemies. Ecol Entomol 27:631-637

Threlfall CG, Walker K, Williams NSG, Hahs AK, Mata L, Stork N, Livesley SJ. (2015) The conservation value of urban green space habitats for Australian native bee communities. Biological Conservation 187: 240-248

Tscharntke T, Klein AM, Kruess A, Steffan-Dewenter I, Thies C. 2005. Landscape perspectives on agricultural intensification and biodiversity - ecosystem service management. Ecology Letters. https://doi.org/10.1111/j.1461-0248.2005.00782.x

United Nations (2018) World Urbanization Prospects: The 2018 Revision. United Nations, New York Viana, B.F., Kleinert, A M.P. \& Imperatriz-Fonseca, V.L.1997.- Abundance and flower visits of social bees in a cerrado of Bahia, tropical Brazil. Stud. Neotrop. Fauna \& Environm. v.31, p.

Wenzel A, Grass I, Belavadi VV, Tscharntke T. 2020. How urbanization is driving pollinator diversity and pollination - A systematic review. Biological Conservation 241: 108321.

Wilms, W; Imperatriz-Fonseca, V.L. \& Engels, W. 1996. Resource partitioning between higly eusocial bees and possible impact of the introduced honey bee on native stingless bees in the Brazilian Atlantic Rainforest. Studies on Neotropical Fauna and Environment. 31: 137-151.

Winfree, R., Aguilar, R., Vázquez, D.P., Lebuhn, G., Aizen, M.A., 2009. A meta-analysis of bees' responses to anthropogenic disturbance. Ecology 90, 2068-2076.

Williams, N.M., Winfree, R., 2013. Local habitat characteristics but not landscape urbanization drive pollinator visitation and native plant pollination in forest remnants. Biol. Conserv. 160, 10-18.

Zanella, F.C.V.; Schwartz Filho, D.L. \& Laroca, S. 1998. Tropical bee island biogeography: diversity and abundance patterns. Biogeographica 74-103-115. 
Zanete, L. R. S. ; Martins, R. P. ; Ribeiro, S.P (2005). Effects of urbanizations on neotropical wasp and bee assemblages in a Brazilian metropolis Landscape and Urban Planning, , v. 71, n. 2-4, p. 105-121, 2005.

\section{Figures}

\section{Figure 1}

Map of Belo Horizonte with the studied fragments

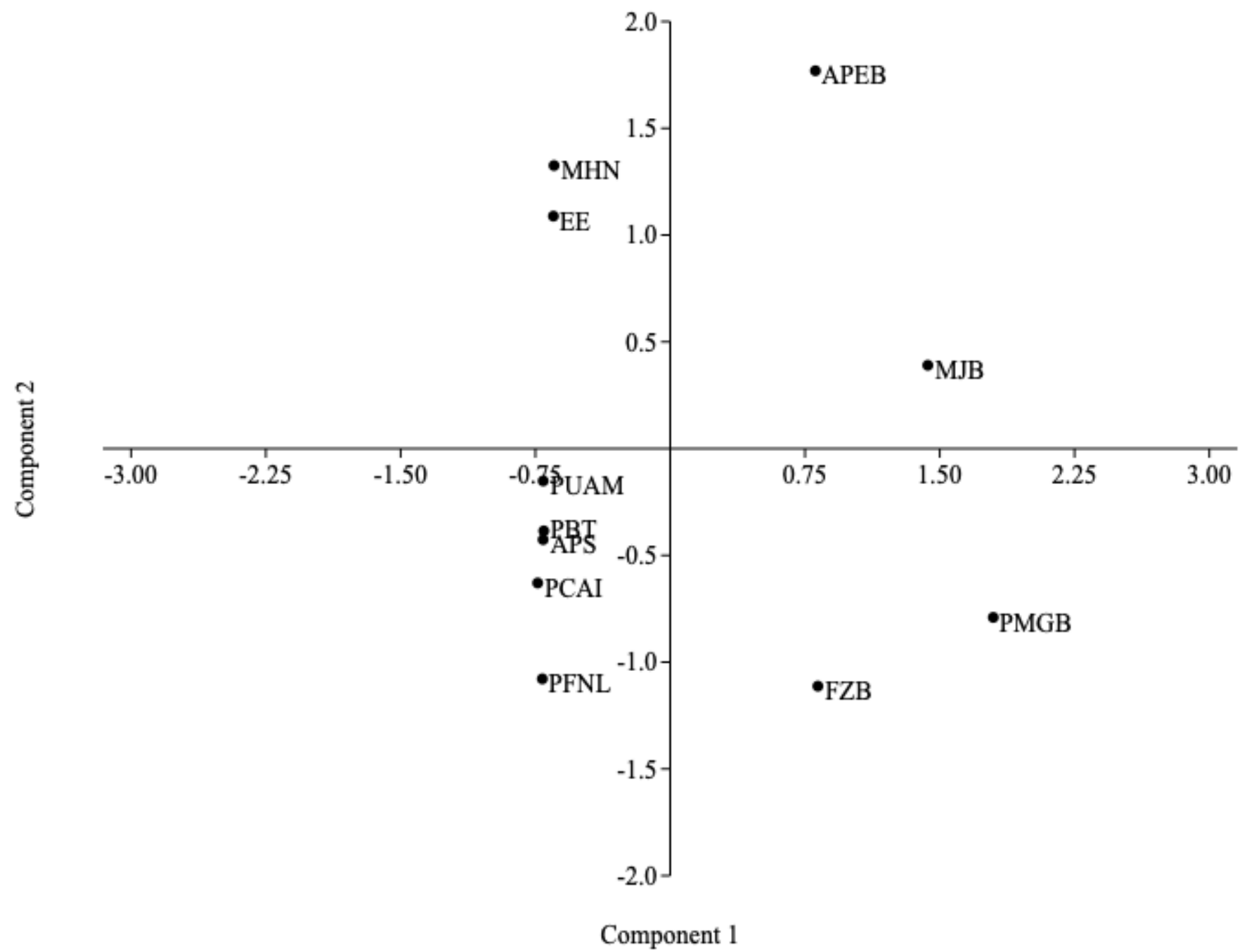

Figure 2

Graphic representation of the PCA analyses, for Melipona quadrifasciata abundance relative to tree abundance and richness; tree height, fragment size and degree of urbanization. 


\section{Figure 3}

Representation of the logistic regression to show the probability of occurrence of Melipona quadrifasciata regarding tree abundance, richness, density and height. Numbers indicate the sites, as in Table 1. Sites below the curve indicates absence of M. quadrifasciata.

\section{Figure 4}

Representation of the logistic regression to show the probability of occurrence of Melipona quadrifasciata degree of urbanization in the landscape and degree of disturbance of the sites Numbers indicate the sites, as in Table 1. Sites below the curve indicates absence of M. quadrifasciata.

\section{Supplementary Files}

This is a list of supplementary files associated with this preprint. Click to download.

- SuplementaryFig1.png 